\title{
Integration of Anti-Corruption Education (PAK) In Islamic Religious Education (PAI) With Neuroscience Approach (Multi-Case Study in Brain Friendly PAUD: I Sleman Kindergarten Yogyakarta)
}

\author{
Suyadi \\ Ahmad Dablan University Yogyakarta, Indonesia \\ suyadi@fai.uad.ac.id
}

\begin{abstract}
This study aims to integrate PAI and Anti-Corruption Education (PAK) with neuroscience approach in PAUD. This research used a qualitative approach in the form of field research in brain-friendly PAUD, i.e. 1 Sleman Kindergarten Yogyakarta. Data collection technique was done by observation, interview, and documentation. Data analysis was done in descriptive, interpretative, and comparative. The research indicates that the application of PAK in I Sleman Kindergarten is by following the findings National Learning Movement of I'm an Honest Kid (Gernas Manjur), while PAI is implemented thematically and scientifically, but it is not yet integrated. This research integrates PAK and PAI by extending the forms of corruption into Gernas Manjur and deepening the themes of PAI learning based on neuroscience learning theory.
\end{abstract}

Keywords: Islamic education, anti-corruption, neuroscience, and early childhood

\begin{abstract}
Abstrak
Tujuan penelitian ini adalah mengintegrasikan PAI dan Pendidkan Anti Korupsi (PAK) dengan pendektan neurosains pada jenang Pendidikan Anak Usia Dini (PAUD). Penelitian ini menggunakan pendekatan kualitif dalam bentuk penelitian lapangan di Pendidikan Anak Usia Dini (PAUD) yang ramah otak, yakni TK N 1 Sleman Yogyakarta. Teknik pengumpulan data dilakukan dengan observasi, wawancara dan dokumentasi. Analisis data dilakukan secara deskriptif, interpretatif dan komparatif. Temuan penelitian menunjukkan bahwa penerapan PAK di TK N I Sleman dilaksanakan dengan mengikuti Gerakan Nasional Pembelajaran Aku Anak Jujur (Gernas Manjur), sedangkan PAI dilaksanakan secara tematik dan saintifik namun keduanya belum terintegrasi. Penelitian ini mengintegrasikan PAK dan PAI dengan cara memperluas bentuk-bentuk korupsi ke dalam Gernas Manjur dan memperdalam tema-tema pembelajaran PAI berdasar teori pembelajaran neurosins.
\end{abstract}

Kata kunci: Pedidikan Islam, anti korupsi, neurosains, dan anak usia dini

Permalink/DOI: http://dx.doi.org/10.18326/infsl3v12i2.307-330 


\section{Introduction}

This research on Islamic education and anti-corruption is based on the results of research conducted by Abdulkareem who found that the world's most corrupt countries are not secular countries, but the Islamic countries, which is Iraq. (Marwah Abdulkareem Mahmood, Yizhuang Tian, 2018). This is reinforced by Gullap survey quoted by ACCH with the title of "obedient in worship but a lot of corruption." Even the survey conducted by Komisi Pemberantasan Korupsi/ KPK (Indonesia's Corruption Eradication Commission) towards 22 central government agencies placed the Ministry of Religious Affairs in the lowest ranked of the corruption integrity index with a score of 5.73, it makes research on corruption and Islamic Education become more interesting.

Research on corruption is mostly based on the theories of politic, law, economics, and psychology. Dejun Tony Kong suggested new theories that have a more transformative impact (Kong, 2017). Referring to Kong's suggestion, this research used a neuroscience approach to integrate Pendidikan Agama Islam/PAI (Islamic Religious Education) and Pendidikan Anti-Korupsi/PAK (Anti-Corruption Education). The use of this neuroscience approach rested on Taufiq Pasiak's theory which stated that corruptors' brain is normal but unhealthy (Pasiak, 2016). Joshua Greene and Jonathan Cohen also stated that only neuroscience has a transformative impact on the prevention of corruption (Greene \& Cohen, 2004). Machfud's article entitled "From Neuron to Narion" also calls for the importance of building the nation's character — including the character of anti-corruption- starting from the very small thing, which is neurons or brain fibers (Suadu, 2016).

Neuroscience has become a new model in the formulation of anti-corruption policies in some countries (Mourao, 2016). For example, Eduardo has developed mirror neurons in neuroscience to explain the theory of corruptors' mind (Foundation \& Rubio, 2008). Nils C. Köbis also developed neuroscience to investigate how the corruptor' make risking decision (Köbis et al., 2016). Therefore, the use of neuroscience in anti-corruption education has a strong theoretical foundation. 
In many countries, anti-corruption education has been widely developed (Abramov \& Russian, 2017), (Flavier, Chikireva, \& Ivanova, 2017) but it is rare to use neuroscience approach, except for Hongkong (Mourao, 2016). For example, Spain developed anticorruption education through advances in information technology (Mattoni, 2017), Serbia against corruption through a system of mutual cooperation (Todora Rogelja, 2017). China is developing anti-corruption education by creating a network of "China online" (Qiao, Training, \& Email, 2017), (Sandri Justiana, Roto Priyono, 2017), (Fabre, 2017).

In Indonesia, anti-corruption education has been widely integrated into various scientific fields, such as PAI, Civics, Mathematics, Architecture, and so on (Fitra, 2015), (Sutrisno, 2017). Integration of PAK and PAI itself has been widely implemented; Rasyidi has been analyzing the anti-corruption education content in PAI (Rasyidi, 2015), Nadri Taja and Helmi Aziz integrated anticorruption values in PAI learning at senior high school (Taja, Nadri dan Aziz, 2016), Luqman Hakim integrated Anti- Corruption in the PAI Curriculum (Hakim, 2012), Kasinyo Harto who discussed religious-based anti-corruption education (Harto, 2014), Harmanto developed PAK through school culture based on Islam (Harmanto, 2012), and so on. However, none of these studies have followed Kong's recommendations in using new approaches, especially neuroscience as in this study.

At the level of Pendidikan Anak Usia Dini/PAUD (Early Childhood Education), neuroscience is a fundamental reference in every learning practice (George S. Morrison, 2012). This is because early childhood brain development (0-6 years) has reached 80\% (Suyadi, 2016), (David A. Sousa, 2012), (Robert Sylwester, 2012). At the stage of Early Childhood Education, PAK is most intensively done, especially with its participation in Gerakan Nasional Pembelajaran Aku Anak Jujur/Gernas Manjur (National Learning Movement of I'm an Honest Kid) in cooperation with KPK.

The latest research that attempted to integrate PAK in early childhood education (PAUD) level is Siswanto (Siswanta, 2017), but did not yet used neuroscience approach. It means, the position 
of this research can be said to continue the previous studies on character education at the level of early childhood (Muntomimah, 2017), (Suparni, 2016), (ZULFITRIA, 2016) but specified on anticorruption character, and added a new approach of neuroscience.

\section{Theoretical Basis}

\section{Anti-Corruption Education (PAK)}

The word corruption comes from the Latin "corruptio" or "corruptus" which means rotten, bad, depraved, dishonest, bribed, immoral, deviation from purity (Karsona, 211AD). Nownes added the term "lobby" commensurate with corruption (Nownes, 2017). In terminology, corruption is defined as an extraordinary crime. The forms of corruption have been clearly described in the 13 articles of Law no. 31 of 1999 jo. UU no. 20 of 2001 covering 7 forms, which are detrimental to state finance, bribery, embezzlement in position, extortion, cheating, conflicts of interest in procurement, and gratuities (KPK, 2006).

In Islam, corruption has many terms, such as al-rishwah, alsubt, and al-ghîl (Umam, 2013), corruption in Arabic, better known as "ghulul" which means embezzlement or "riswab" which means bribe or equivalent to other words such as ghasbah (fraud), khiyanat (abuse of authority), and maksu (illegal charges) (Mustakim, 2013). The Tarjih Assembly of Muhammadiyah Central Board issued a fatwa that corruption is a "great shirk" so that this sin is not forgiven by Allah SWT (Anwar, 2006). Ulama of Nahdlatul Ulama also issued a fatwa stating that corruption is a very big munkar (dishonor), so it deserves to be sentenced to death and the people no need to salah for the corpse (Alim, 2017).

Based on the analysis of etymology and terminology above, the researcher argues that "corruption" is an act of rotten akblaq (moral), extraordinary crime, major sin, and unlawful act, both state law and religious law-including social norms and order, purposing in self/groups benefit, abuses the roles, authorities, powers, and positions that can harm the state finances. 
Islamic Religious Education (PAI) in Early Childhood Education (PAUD) Level

Islamic Education and Islamic Religious Education (PAI) are still frequently interchanged. In terminology, "Islamic Education" (without the word 'Religion') is actually the same as 'Islamic Religious Education' because Islam is the name of a religion. But etymologically, they have different meanings; Ahmad Tafsir defined "Islamic Education" (without religion) as a system, i.e. an Islamic of education system, so that other related components (theory, curriculum, method, evaluation, and so on) are derived from the Quran and Hadith as well as distinguish it from the general education system or other "non-Islamic Education". While the term Islamic Religious Education (PAI), in addition to has been standardized into the name of a subject in the school it also means as "the name of learning activities." Therefore, the system name is "Islamic Education", but the name of learning activities called Islamic Religious Education (PAI). Islamic religious research here refers to learning activities, not education systems based on the Quran and Hadith.

Government Regulation No. 55 of 2007 on Religious Education and Religiosity article 3 stated that every educational unit in all pathways, levels, and types of education must carry out religious education. PAI at early childhood education (PAUD) level is organized thematically in accordance with the Curriculum 2013 of PAUD (Salim, 2014). Alternatively, PAI at early childhood education level follows the Directorate General of PAUD, which is based on Islamic Religious Education or PAUD based on PAI (Dirjen PAUD, 2015). In its implementation, PAUD based on PAI is conducted by following the curriculum regulation, i.e. Curriculum 2013 of PAUD (Dahlia, 2014).

Early childhood education (PAUD) itself has three types with different levels, which are daycare at an informal level, Play Group at the non-formal level, and kindergarten at formal level (Suyadi dan Maulidya Ulfa, 2013). Based on the government regulation number 55 of 2007 above, then early childhood education (PAUD) in various forms and levels must hold religious education, including Islamic religiosity or PAI. 


\section{Neuroscience, Normal Brain in Corruptors}

Neuroscience is a neural science that studies the nervous system, especially studying neurons or nerve cells, with a multidisciplinary approach (Pasiak, 2016). Neuroscience is also a field of science specializing in scientific studies of the nervous system (neuroanatomy) and all neurological functions (neurophysiology). This science is a science that progressed very rapidly in the twentieth century, passing in various other disciplines, such as psychology (neuro-psychology), economics (neuro-economics), leadership (neuro-leadership), marketing (neuro-marketing), education (neuroeducation), arts (neuro-arts), and so forth (Ikrar, 2016).

In the context of Islamic education, Suyadi has laid the groundwork for a new science which he calls the neuroscience of Islamic education (Suyadi, 2015b). On neuroanatomy, the biological organs of neuroscience in the Quran can be found in QS. Al-Alaq (15-16) which is represented by the word "nasiyab" (crown head), which in the perspective of the science, nasiyah can be interpreted as "the brain" especially the prefrontal cortex (McKlveen, Myers, \& Herman, 2015), (ITB, 2014). On neurophysiology, which is the function of the brain, the Quran is very rich in neuroscience. This can be traced to ayah that use the word ' $a q l$ (reason) and the equivalent words, such as: dabbara (contemplate), faqiha (know), fabima (understand), nazhara (see with the eyes of the head), dzakara (remember), fakkara (deep thinking), and alima (understand clearly) (Taufiq Pasiak, 2008).

The main purpose of this science is to understand the biological basis of every behaviors or character, including the character of anti-corruption. ISHA results showed that corruptors' brain is known to be normal but unhealthy (Taufiq Pasiak, 2012a). The main task of neuroscience is to explain human behavior from the action point of view that occurs in the brain. Recent research in the field of neurosciences finds some evidence of an inseparable link between brain and human behavior (character) (Taufiq Pasiak, 2012b).

Through the Positron Emission Tomography (PET) instrument it is known that there are six brain systems integrate all human 
behavior. These six brain systems are the cortex prefrontalis, the limbic system, the gyrus cingulatus, ganglia basalis, lobus temporalis, and cerebellum. These six brain systems work cohesively or shoulder to shoulder to build human attitudes and behavior. Therefore, regulating the performance of the brain normally will produce optimal function, so that behavior can be controlled consciously by involving the emotional and spiritual dimension.

\section{Research Method}

The approach used in this research was qualitative in the form of field research. The setting was early childhood education (PAUD) institution that meets the criteria as a brain-friendly education institution, i.e. I Sleman Kindergarten Yogyakarta. Data collection technique was done by observation, interview, and documentation. Observations were conducted periodically and continuously for six months, both for teachers and students in internal and external learning activities, especially the instructors of Gernas Manjur. Documentation was done to look for related literature, including administrative documents, such as the Rencana Pelaksanaan Pembelajaran Harian/RPPH (Daily Lesson Plan), school curriculum, and other learning resources.

This research was conducted in three stages. First, the classification of early childhood education (PAUD) institutions that organize PAK with reference to neuroscience learning theories (Suyadi, 2016). The result of classification found out one of PAUD institution that fulfill this criterion, which was I Sleman Kindergarten Yogyakarta. Second, observation to observe the implementation of PAK and PAI at I Sleman Kindergarten Yogyakarta in learning core activities, extracurricular, and accidental activities. Third, interviews with teachers about the understanding of anti-corruption education, and also school patterns in integrating it in Islamic religious learning with reference to the theory of neurosciences. Interviews were also conducted with parents and children according to their proportion, in order to understand the perceived usefulness of the application of anti-corruption education. Interviews were clarified with supporting documents, i.e. lesson plan and curriculum books. 
The collected data were analyzed in descriptive, interpretative, and comparative. The observation data was clarified with interview data, confirmed with supporting documentation, and then interpreted descriptively. Interpretation of data was done by theocratization to develop integration model or formula of PAK and PAI through neuroscience approach in I Sleman Kindergarten Yogyakarta.

\section{Analysis: PAK, PAI, and Neurosciences in Brain Friendly PAUD, I Sleman Kindergarten Yogyakarta}

Brain-friendly PAUD is a term introduced by the researcher to call early childhood education institutions that the learning is based on neuroscience learning theories. Morrison pointed out that current findings in the field of neuroscience are an important reference for early childhood learning (George S. Morrison, 2012). David Souasa also pointed out that although educators are not brain experts but educators are professions whose work changes the brain every day (David A. Sousa, 2012). In fact, Robert Silweter stated that for centuries educators have changed the brain without a little bit knowledge about neurosciences (Robert Sylwester, 2012). Therefore, brain-friendly PAUD is PAUD that the teachers understand neurosciences so they can organize teaching and learning process based on neuroscience learning theory.

I Sleman Kindergarten Yogyakarta is one of the formal early childhood institutions that meet the criteria above. Although this kindergarten does not make the brand as a brain-friendly Kindergarten, its learning process refers to neuroscience learning theory. Ms. Darmi, a teacher of I Sleman Kindergarten Yogyakarta pointed out that "We often attend seminars on children's brain development and appropriate learning methods then apply them in daily learning practices." This is different from Khalifah Kindergarten Purworejo that has the brand as "right brain based kindergarten" but the learning process is less refers to the theory of neurosciences learning (Siswandi, 2018). Thus, what determines whether an educational institution is brain-friendly or not is the learning process.

I Sleman Kindergarten Yogyakarta has 28 teachers and all of them are women. The phenomenon of early childhood teachers' 
dominance by women is interesting to be observed in relation to women growing interested in anti-corruption activists as stated by Qurirah (Feni Qoriroh, 2016) and Revita (Revita, 2016). In fact, the study of Lu'mu Taris showed the symptoms of the existence of gender-based anti-corruption education (Lu'mu Taris, 2016). Thus, I Sleman Kindergarten has great potential for the application of brain-friendly or neuroscience-based anticorruption education.

\section{Gernas Manjur: Anti-Corruption Education in I Sleman Kindergarten}

Anti-Corruption Education (PAK) in I Sleman Kindergarten was realized in Gerakan Nasional Pembelajaran Anak Jujur/Gernas Manjur (National Learning Movement of I'm an Honest Kid). In Gernas Manjur there is only one character value of anti-corruption, because according to Ekowati, at early childhood level is just need one value, which is honesty (Siti Ekowati Rusdini, Maman Rachman, 2016). The implementation of PAK at the Kindergarten level through Gernas Manjur also distinguishes the implementation of PAK on the education level above it, such as social capital conducted by Nurdyansyah (Nurdiyansyah, 2015). In the context of neurosciences, honesty is one indicator of a healthy brain.

Gernas Manjur is a movement initiated by Himpunan Pendidikan Anak Usia Dini Indonesia/HIMPAUDI (Community of Early Childhood Education Indonesia) in cooperation with Corruption Eradication Commission (KPK) in the 3rd National Working Meeting in Jakarta on February 14, 2016. This movement is motivated by HIMPAUDI's anxiety towards a big number of officials who are corrupt, and the phenomenon of deviant behavior, problematic to corrupt behavior-distinguish corruptive behavior from corruption criminal act-both on children and adolescents.

Gernas Manjur was first performed simultaneously in all districts of Indonesia on 20 May 2016 as the National Revival Day. The educator conducts a learning of "I'm an honest kid" with children in their early childhood institutions using Dongeng Musik dan Permainan/DOMAIN (Tale, Music, and Games) method and 
adheres to the 10 principles of early childhood, which are: (1) Learning Through Playing, (2) Children development-oriented, (3) children's needs oriented, (4) Children-centered, (5) Active learning, (6) Oriented on the development of character values, (7) Oriented in the development of life skills, (8) Supported by a conducive environment, (9). Oriented to democratic learning, (10) Utilization of learning resource media and resource persons. The ten principles of early childhood learning have accommodated the 10 basic laws of the brain as proposed by Pasiak (Pasiak, 2009), and have been elaborated in various theories of neurosciences as proposed by Suyadi (Suyadi, 2016).

Ms. Darmi, a teacher of I Sleman Kindergarten said that the movement was only launched on 20 May 2016 and until now there has been no follow-up. She also said that the children were only asked to watch "Film Si Kumbi Anak Jujur (Kumbi the honest kid)" but in everyday practice, we rarely play back the children movie from the KPK. If the implementation of Gernas Manjur in I Sleman Kindergarten is clarified with technical manual Gernas Manjur (Himpaudi, 2016), it is still far from expectations, because it has not fulfilled the 7 elements in the technical guidelines, i.e.: Make $R P P H$ which will be used in Gernas Manjur activity on 20 May 2016 with the theme I'm an Honest Kid. RPPH containing: date, month, year of use of RPPH, theme/sub-theme, time allocation, learning materials, learning strategies, APE, learning resources in the environment, and assessment.

1. RPPH implemented by educators with students that contain elements of opening, core, and closing activities.

2. The RPPH should cover 5-6 aspects of children development, i.e. religious and moral values, cognitive, language, emotional, physical, motor, and art.

3. RPPH must integrate 3 main activities, i.e. tale, music, and games (DOMAIN).

4. Evaluation of learning that includes process evaluation and outcomes conducted by educators to assess the implementation of the Gernas Manjur plan.

5. Early Childhood Institution documented all activities in the form 
of RPPH, photos, videos, brief narration/activity description, and other documents deemed necessary.

6. Send all the documents to each PC, if the PC does not implement it, then it can be sent to PD.

The seven technical requirements above are still far from expectations. For example, Gernas Manjur activities are not implemented in each early childhood institution but centered on one big point (I Sleman Kindergarten joins Graha Sabha Pramana of Gadjah Mada University building). Teachers do not make RPPH because all activities of children are conditioned in a classical manner on a large scale and guided by instructors from HIMPAUDI. The opening, core, and closing activities - which cover the tale, music, and games) are entirely filled with watching a movie called "Si Kumbi Anak Jujur." Thus, the five aspects of children development and the 10 principles of early childhood learning have not been well implemented in this Gernas Manjur.

\section{Thematic Integrative and Scientific of Islamic Religious Education in I Sleman Kindergarten}

Quraish Shihab's Tafsir Al-Misbah using the maudhu'i (موضوعي) approach or thematic approach (Saha, 2015) basically in line with PAI learning in Curriculum 2013 (Dirjen PAUD, 2015). Tafsir Ilmi stated that the Quran contains $70 \%$ of qauniyah ayah or universe proofs (sciences), while the rest are kauliyah ayah (aqeedah, fiqh, and ibadat) in which also relevant to the Curriculum 2013 of PAI (Tim Penyusun Kementerian Agama RI, 2016). (Kementerian Agama RI dan Ilmuwan LIPI). Therefore, the implementation of PAI with a thematic approach in I Sleman Kindergarten is in accordance with the Curriculum 2013 of PAI, thus linking the qauliyah and qauniyah.

According to Ms. Darmi, Teacher in N I Sleman Kindergarten, PAI in I Sleman Kindergarten in addition to being integrated thematically in learning, also done in a special and separate or independent. Every day before the core activities begin the teachers always introduces the letters of hija'iyah (Quran Hadith) with the Iqra method. Furthermore, in opening activities, the teacher telling story/tale/Islamic story (History of Islamic Culture). The stories 
most often are the stories of the Prophets. According to Jalaluddin Rahmat, great stories can cultivate children's spirituality (Rahmat, 2006) or in terms of neuroscience called spiritual circuits. Entering the core activities, the children are invited to practice dhuha prayer (fiqh ibadat), start from washing ( $w u d h u)$ and praying practice. Other activities are various, between memorizing short letters and daily duas as well as other Islamic religious learning materials, such as pillars of faith, pillars of Islam, fasting, pilgrimage (small hajj manasik) and so forth.

PAI with a material scope of Quran-Hadith, Fiqh, History of Islamic Culture, and Aqeedah Akhlaq as mentioned above, certainly includes all the values of morality, including the value of honesty in Gernas Manjur. On this basis, I Sleman Kindergarten has a perception that with PAI, it will automatically teach anti-corruption values. Ms. Darmi, said, "For us in the PAI must teach the values of anti-corruption." The same is also conveyed by Ms. Eni, PAI teacher of I Sleman Kindergarten stated that "PAI automatically also develops Islamic character, including honesty in anti-corruption education. "For teachers at I Sleman Kindergarten, the essence of Gernas Manjur is PAI itself.

The statement of Ms. Darmi and Ms. Eni showed that there is an exaggerate assumption on PAI, the automation of anti-corruption education. Similar assumptions or perceptions also occur in character education, i.e. schools that have implemented PAI also automatically apply character education (Harmanto, 2012), (Harto, 2014). In fact, as mentioned above, that only PAI is not enough to foster the character of anti-corruption. The proof is the case presented by Ms. Eni:

"When drawing and coloring activities, teachers facilitated colorful pencils to children. After the activity was finished and all the children returned the colored pencils, there were some broken pencil leads, therefore no child honestly admitted that he/she broke it." Although Ms. Eni has made it clear that honesty is a good deed that loved by Allah and Rasulullah even teachers and friends, but still no one confessed, so Ms. Eni forced to do an interrogation. After interrogation, there was one child who dares to report that he/she sees that "A" child doing it. Ms. Eni specifically called A and finally, A told her that he broke school's pencil leads." 
Ms. Eni also said that there are many incidents of dishonesty among children, including how children are hard to admit the mistakes they made. For example, when children playing toys together then there is a fight for the toys so that the toys are broken, but among children blame each other, then that's where the symptoms of corrupt behavior begin. This reflects how fragile the value of honesty and courage in children. If this is left repeatedly for extended periods of time, even more so until children grow up and become public officials or state organizers, then it is certain that they will become corruptors. Why is that? Because dishonest characters have been firmly entrenched, ingrained, and embedded in them so that the character will always be carried out when doing any activities.

The data of I Sleman Kindergarten above is one form of corrupt behavior that spread among the children. In the context of neuroscience, children with corrupt behaviors are children who have normal brain but unhealthy or can be called cognitive pathology (Suyadi, 2015a). In the context of social life, if a person is silent when seeing a cheating behavior, and does not dare to report to the authorities, then it includes corrupt behavior (KPK, 2006). In this case, an important note that should be underlined is that PAI learning alone is not enough to foster the value of honesty in the students. On this basis, this is the importance of anti-corruption education integration in PAI learning.

\section{Integration of Anti-Corruption Education in PAI with Neuroscience Approach}

Based on the above explanation, it can be understood that the PAI learning in N I Sleman Kindergarten is conducted following the Curriculum 2013 of PAUD, i.e. thematic integrative and scientific (Dahlia, 2014). This pattern is in accordance with tafsir science, a collaboration work of Ministry of Religious Affairs and Indonesian Institute of Sciences/LIPI (Tim Penyusun Kementerian Agama RI, 2016). While anticorruption education is done through a Gernas Manjur that pays attention to 5 aspects of children development and refers to the 10 principles of 
learning in early childhood and using the method DOMAIN (Tale, Music, and Games). In the perspective of neuroscience, the 10 principles of early childhood learning are in harmony with the 10 basic laws of the brain, when the DOMAIN method, especially tales, can serve as a medium for spiritual circuit activation.

However, PAI and Gernas Manjur in I Sleman Kindergarten seem to be secluded or not yet integrated. As a result, the corrupt behaviors that arise among children cannot be detected and anticipated. This is because teachers have not used new methods or new approaches, especially neuroscience in integrating PAK and PAI in I Sleman Kindergarten. Moreover, the teachers still believe that PAI will automatically teach honesty and thus has conducted anti-corruption education. Although this view has a point, in fact, many Muslims is devout in worship but their behavior are corrupt. This indicates that PAI alone is not sufficient to prevent corruption, so it needs to be intertwined with the PAK with a new approach, which is neuroscience.

As an academic contribution, this research analysis offers an integrated model of PAI and PAK with neuroscience approach that can be applied in I Sleman Kindergarten in particular and other early childhood education institutions in general. This model is limited to reconstructing learning practice artifacts, both PAI and PAK into a complete configuration. Referring to the theory and data in the above description, conceptually, the design of PAI and PAK integration with neurosciences is the actualization of anti-corruption values, especially honesty as in Gernas Manjur. It is expanding the forms of corruption and promoting the development of scientific integrative thematic PAI themes with attention to 5 aspects of children development, 10 principles of early childhood learning and refers to neuroscience learning theory and using the DOMAIN method. Figure 1 illustrates the interaction model of PAI and PAK at the early childhood education level. 


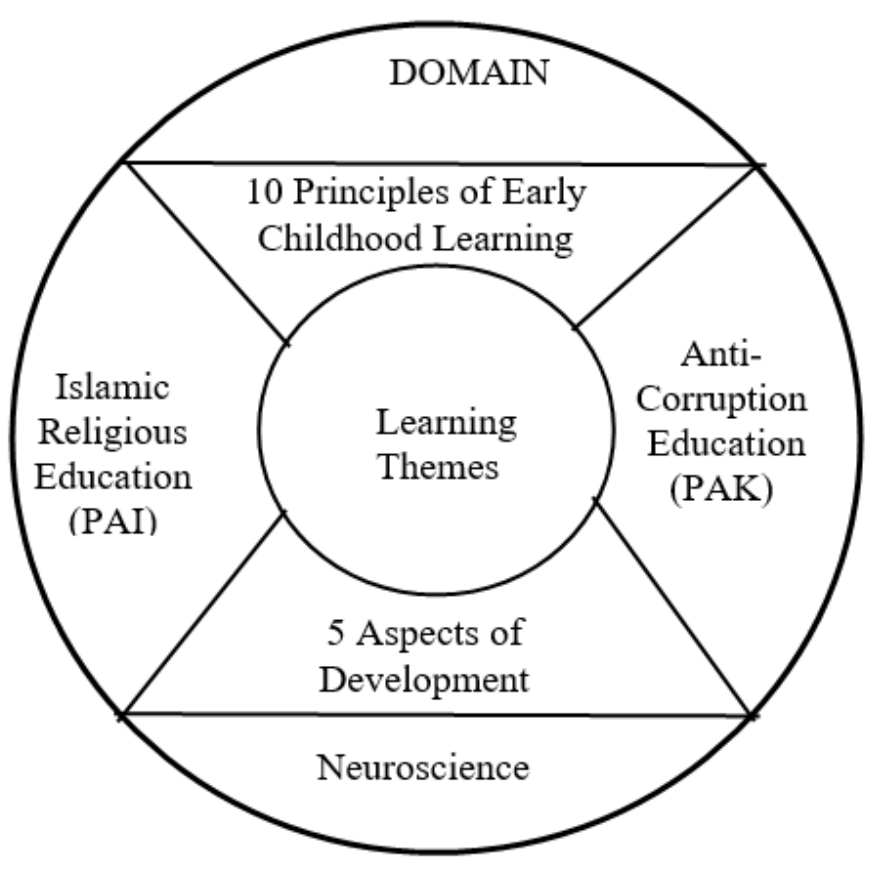

Figure 1.

\section{Integration model of Islamic Religious Education (PAI) and Anti-Corruption Education (PAK) with neuroscience approach}

Figure 1 above explained that the themes in early childhood learning are the result of the integration of PAK and PAI through neuroscience approach that considers 5 aspects of children development and 10 principles of early childhood education learning with the DOMAIN method. There are several concepts in Figure 1 above that need to be explained. Anti-corruption education is an extension of 7 forms of corruption into the daily lives of learners. For example, the corruption form of "detrimental to state finances" can be expanded to the detriment of families, environment, schools, and so on. The form of actions can be various. For example, students who deliberately destroy school facilities are included in 
the category of expansion of this corrupt behavior. Another example is throwing away trash that causing the emergence of disease nest so that the country must scathe because it subsidizes patients. Corruption form of "fraudulent acts" can be expanded by the act of cheating, deceiving, provoking, and so forth. Further until 7 forms of corruption can be understood by students according to its context.

PAK at early childhood education level in the form of Gernas Manjur needs to be actualized more intensively so that the value of honesty is not only in word, but real actions. Teachers need to engineer the class in such a way as to stimulate the students' courage to be honest. For example, during the morning snack, the teacher provides a number of children's cakes in deliberate excess, then the children are asked to take their own meals. Each child may only take one cake so that if there are children who take more than one can be known; or the teacher deliberately excess the cakes, so if the cakes lost means there are children who take more than one.

Based on the elaboration, the themes of early childhood learning can be formulated. For example is environmental themes. This theme can contain a clean and beautiful environment or a dirty and damaged environment. The neuroscience approach in this theme can be done by stimulating the spiritual circuit through deep meaning, such as reflecting on the environment as God's creation that must be kept and preserved; the act of damaging the environment is corrupt behavior or morally disgraceful. In order for this activity to also develop the five aspects of children development as well as the ten principles of early childhood learning with tale methods, this theme needs to be formulated in a number of activities that are intelligent, interesting, inspirational, and religious. For example, drawing and coloring the mosque environment (developing religious and cognitive aspects), processing waste into arts (motoric and artistic development), and adding stories or tale related to the environment (language development). Teachers creativity determines the integration of PAI and PAK through neuroscience approach that can occur in one learning theme, which also has a transformation for the five aspects of children development. 


\section{Conclusion}

Based on the analysis and discussion above, it can be concluded that PAI, which is taught in all levels of education, is not enough to develop anti-corruption behavior so that PAI needs to be integrated with PAK. Considering that a lot of research has been done on the integration of PAK into various fields of science but not yet has a more transformative impact, this study follows Kong's recommendation to use a new approach, i.e. neuroscience. Thus, the integration of PAK and PAI has an advantage in terms of the approach being used, i.e. neuroscience, so that it has a more transformative impact.

PAK in the early childhood, especially I Sleman Kindergarten Yogyakarta, held in the form of Gernas Manjur. While the PAI is organized thematically following the regulations of Curriculum 2013 of PAUD. However, both of them are running separately and even far from expectations. On one hand, Gernas Manjur has not been in accordance with technical provisions, on the other hand, PAI is considered to automatically develop the learners' anti-corruption character. Therefore, researchers integrate both as solutions or academic offers.

The results of PAK and PAI integration are carried out by expanding the forms of corruption in the context of the students' daily lives and deepening the themes of PAI learning by considering the five aspects of development and using the DOMAIN method. Thus, the themes of learning in early childhood education, especially I Sleman Kindergarten, are a description of the results of the integration of PAK and PAI. In this case, the teachers' creativity is needed to realize this concept. 


\section{Reference}

Abramov, R. A., \& Russian, P. 2017. Evaluation of The Effeciveness of Russian Anti-Corruption State Policy in The Fieldof Education. Journal of Legal, Ethical and Regulatory Issues, 20(1), 1-10.

Alim, M. W. dan H. (Ed.). 2017. Jihad Nahdlatul Ulama Melawan Korupsi. Jakarta: Lakpesdam-PBNU.

Anwar, S. 2006. Fikih Anti Korupsi Perspektif Ulama Mubammadiyah. Jakarta: Majelis Tarjih dan Tajdid Pimpinan Pusat Muhammadiyah.

Dahlia, S. dan. 2014. Implementasi dan Inovasi kurikulum PAUD 2013. Bandung: Rosda Karya.

David A. Sousa. 2012. Bagaimana Otak Belajar Edisi Keempat. Jakarta: Indeks. Retrieved from http://www.indeks-penerbit. $\mathrm{com} /$ index.php?route $=$ product $/$ product $\&$ product_id $=444$

Dirjen PAUD. 2015. PAUD Berbasis Pendidikan Agama Islam. Jakarta: Kemendikbud.

Fabre, G. 2017. XXI Jinping's Challenge: What Is Behind China's Anti-Corruption Campaign? Journal of Self-Governance and Management Economics, 5(May 2016), 7-28.

Feni Qoriroh, M. M. K. S. 2016. Partisipasi Aktivis Saya Perempuan Anti Korupsi (SPAK) dalam Upaya Pendidikan Antikorupsi di Surabaya. Kajian Moral Dan Kewarganegaraan, 3(4), 12791291.

Fitra, M. 2015. Pendidikan Anti Korupsi melalui Kehadiran Arsitektur. Jurnal Sains Dan Seni ITS, 4(2), 19-22.

Flavier, H., Chikireva, I., \& Ivanova, K. 2017. Disciplinary responsibility's application to the local government employees violating the anti-corruption legislation in the russian federation, europe and the united states of america. Brics Law Journal, IV(4), 116-144. https://doi.org/10.21684/24122343-2017-4-4-116-144 
Foundation, V., \& Rubio, M. 2008. Mirror Neurons , Theory of Mind and Corruption (pp. 1-2). https://doi.org/10.2139/ ssrn. 1341355

George S. Morrison. (2012). Dasar-dasar Pendidikan Anak Usia Dini (PAUD). Jakarta: Indeks.

Greene, J., \& Cohen, J. 2004. For the law, neuroscience changes nothing and everything. In The Royal Society (pp. 1775-1785). https://doi.org/10.1098/rstb.2004.1546

Hakim, L. 2012. Model Integrasi Pendidikan Anti Korupsi dalam Kurikulum Pendidikan Islam. Taklim, 10(2), 141-156. Retrieved from http://jurnal.upi.edu/taklim/view/2270/ MODEL INTEGRASI PENDIDIKAN ANTI KORUPSI DALAM KURIKULUM PENDIDIKAN ISLAM

Harmanto. 2012. Pendidikan Anti Korupsi Melalui Budaya Sekolah Berbasis Nilai-Nilai Keislaman. Islamica, 7(1), 101-122.

Harto, K. 2014. Pendidikan Anti Korupsi Berbasis Agama. Iurnal Intizar, Vol. 20, No. 1, 2014, 20(1), 121-138.

Himpaudi. 2016. Jukni Gernas Manjur (Gerakan Nasional Pembelajaran Aku Anak Jujur). Jakarta: Himpaudi.

Ikrar, T. 2016. Ilmu Neurosains Modern. Yogyakarta: Pustaka Pelajar.

ITB, T. T. I. salman. 2014. Tafsir Salman: Tafsir Ilmiah Juz'amma. Bandung: Mizan dan YPM Salman ITB.

Karsona, A. M. (211AD). Pengertian Korupsi. In Pendidikan Anti Korupsi untuk Perguruan Tinggi (p. 23). Jakarta: Kementerian Pendidikan dan Kebudayaan RI Direktorat Jenderal Pendidikan Tinggi.

Köbis, N. C., Prooijen, J. Van, Righetti, F., Lange, P. A. M. Van, Watkins, H. M., Gawthorpe, S., \& Odenkirchen, J. J. 2016. Prospection in Individual and Interpersonal Corruption Dilemmas (Vol. 20, pp. 71-85). 
Kong, D. T. 2017. An economic - genetic theory of corporate corruption across cultures : An interactive effect of wealth and the 5HTTLPR-SS / SL frequency on corporate corruption mediated by cultural endorsement of self-protective leadership. PERSONALITY AND INDIVIDUAL DIFFERENCES, 63(November), 106-111. https://doi.org/10.1016/j. paid.2014.01.061

KPK. 2006. Memahami Untuk Membasmi. Jakarta: KPK.

Lu'mu Taris, M. R. 2016. Implementasi Media Pembelajaran Anti Korupsi Berbais Gender Untuk Menanamkan Nilai-Nilai Kejujuran di SD. Jurnal Penelitian Pendidikan INSANI, 19(2), 100-107.

Marwah Abdulkareem Mahmood, Yizhuang Tian, K. A. A. 2018. How Corruption Affects Economic Growth : Perception of Religious Powers for Anti- corruption in Iraq How Corruption Affects Economic Growth : Perception of Religious Powers for Anti-corruption in Iraq (pp. 1465-1474). Singapore: Springer International Publishing AG. https://doi.org/10.1007/978-3319-59280-0

Mattoni, A. 2017. From Data Extraction to Data Leaking: Dataactivism in Italian and Spanish anti-corruption campaigns. Partecipazione e Conflitto, 10(3), 723-746. https://doi. org/10.1285/i20356609v10i3p723

McKlveen, J. M., Myers, B., \& Herman, J. P. 2015. The Medial Prefrontal Cortex: Coordinator of Autonomic, Neuroendocrine and Behavioural Responses to Stress. Journal of Neuroendocrinology, 27(6), 446-456. https://doi.org/10.1111/ jne. 12272

Mourao, L. 2016. Neuroscience: A New Model For Anticorruption Police?

Muntomimah, S. 2017. Model Pendidikan Karakter Anak Usia Dini di Pondok Pesantren Al Hikam Kota Malang. JIP, 7(1), 43-51. 
Mustakim, M. 2013. Wawasan Al-Quran tentang Pendidikan Anti Korupsi. Jurnal Ilmu Tarbiyah "At-Tajdid," 2(1).

Nownes, A. 2017. Lobbying: The preconditions of an anti-corruption promise. Anti-Corruption Resource Centre (Vol. 4). Australia.

Nurdiyansyah. 2015. Model Social Reconstruction Sebagai Pendidikan Anti - Korupsi Pada Pelajaran Tematik di Madrasah Ibtida ' iyah Muhammadiyah 1 Pare Nurdyansyah. HALAQA: Jurnal Pendidikan Dan Keislaman, 14(1), 13-22.

Pasiak, T. 2009. Unlimited Potency of the Brain: Kenali dan Manfaatkan Sepenubnya Potensi Otak Anda yang Tak Terbatas. Bandung: Mizan Bandung. Retrieved from http:// mizan.com/index.php?fuseaction=buku_full\&id=2629

Pasiak, T. 2016. Tuhan Dalam Otak Manusia : Mewujudkan Kesehatan Spiritual Berdasarkan Neurosains. Mizan, Bandung.

Qiao, Z., Training, P. D. C., \& Email, B. 2017. Chinese Anti-Corruption Policy Choices in a Transitional Stage. Journal of Postdoctoral Research, 5(7), 9-18.

Rahmat, J. 2006. SQ For Kids. Bandung: Mizan.

Rasyidi. 2015. PENDIDIKAN ANTI KORUPSI DALAM PENDIDIKAN AGAMA ISLAM. Jurnal Tamaddun Ummah, VOL. 01 NO(1), 1-12. Retrieved from http://www.iaitfdumai.ac.id/wpcontent/uploads/2016/04/Rasyidi-M.Pd_.I.pdf

Revita, I. 2016. Pendidikan Anti Korupsi dalam Pencegahan Aktifitas Women Trafficking di Indonesia. Jurnal Al-Ta'dib, 9(1), 6075 .

Robert Sylwester. 2012. Memahami Perkembangan \& Cara Kerja Otak Anak-anak. Jakarta: Indeks. Retrieved from MemahamiPerkembangan-\%26-Cara-Kerja-Otak-Anak-anak.html

Saha, S. 2015. Perkembangan Penulisan Tafsir Al-Qur' an di Indonesia Era Reformasi. Jurnal Lektur Keagamaan, 13(1), 59-84. 
Salim, A. 2014. Pendekatan Saintifik dalam Pembelajaran Pendidikan Agama Islam (PAI) di Madrasah. Cindekia, 12(1), 33-48.

Sandri Justiana, Roto Priyono, E. M. (2017). Using Board Games as Anti-Corruption and Integrity Learning Media. Journal of Game, Game Art, and Gamification, 02(02), 177-179.

Siswandi, N. A. W. 2018. Manajemen Program Kegiatan PAUD Berbasis Otak Kanan. Awlady: Jurnal Pendidikan Anak, 4(1), 98-118.

Siswanta, J. 2017. Pengembangan Karakter Kepribadian Anak Usia Dini ( Studi Pada PAUD Islam Terpadu Di Kabupaten Magelang Tahun 2015 ). Inferensi, Jurnal Penelitian Sosial Keagamaan, 11(1), 97-118.

Siti Ekowati Rusdini, Maman Rachman, E. H. 2016. Pelaksanaan Internalisasi Kejujuran dalam Pendidikan Antikorupsi di SMP Keluarga Kudus. Journal of Educational Social Studies, 5(1), 24-32.

Suadu, F. 2016. Neuron To Nation, Narasi Pembangunan Bangsa Berbasis Mental (Otak) Manusia. Gorontalo: Avicena.

Suparni. 2016. Metode Pembelajaran Membaca Doa Berbasis Multimedia Untuk Anak Usia Dini, 2(1), 1-8. Retrieved from http://ejournal.bsi.ac.id/ejurnal/index.php/ijse/article/ view/668

Sutrisno, M. M. 2017. Pengembangan Modul Pendidikan Anti Korupsi Pada Mata Pelajaran Pendidikan Pancasila dan Kewarganegaraan Untuk Kelas X Sekolah Menengah Atas. Harmoni Sosial: Jurnal Pendidikan IPS, 4(1), 55-66.

Suyadi. 2015a. Aku Pablalwan Kejujuran; Seri Pendidikan Anti Korupsi Untuk SD/MI; SMP/MTS \& SMA/MA/SMK. Yogyakarta: Andi Ofset.

Suyadi. 2015b. Dasar-Dasar Pemikiran Menuju Ilmu Neurosains Pendidikan Islam. Yogyakarta: Sunan Kalijaga State Islamic University. 
Suyadi. 2016. Teori Pembelajaran Anak usia Dini Dalam Kajian Neurosains. Bandung: Remaja Rosdakarya. Retrieved from http://www.bukukita.com/Orang-Tua-dan-Keluarga/ Psikologi-\&-Pendidikan-Anak/129444-Teori-PembelajaranAnak-usia-Dini-Dalam-Kajian-Neurosains.html

Suyadi dan Maulidya Ulfa. 2013. Konsep Dasar PAUD. Bandung: Remaja Rosdakarya. Retrieved from https://www.tokopedia. com/bukukita/konsep-dasar-paud-oleh-suyadi-dan-maulidya

Taja, Nadri dan Aziz, H. 2016. Mengintegrasikan Nilai-Nilai Anti Korupsi Dalam Pembelajaran Pendidikan Agama Islam. Jurnal Pendidikan Agama Islam, Vol. XIII, 39-51. Retrieved from https://media.neliti.com/media/publications/117196ID-mengintegrasikan-nilai-nilai-anti-korups.pdf

Taufiq Pasiak. 2008. Revolusi IQ/EQ/SQ: Menyingkap Rahasia Kecerdasan Berdasarkan Al-Quran dan Neurosains Mutakhir. Bandung: Mizan Bandung. Retrieved from http:// www.bukukita.com/Agama/Islam/57846-Revolusi-IQ-EQSQ-:-Menyingkap-Rahasia-Kecerdasan-Berdasarkan-AlQuran-dan-Neurosains-Mutakhir

Taufiq Pasiak. 2012a. Antara 'Tuhan Empirik' dan Kesehatan Spiritual. In Taufiq Pasiak (Ed.), book section. Yogyakarta: Centre for Neuroscience, Health and Spirituality [C-NET].

Taufiq Pasiak. 2012b. Pendidikan Karakter sebagai Pendidikan Otak. In Mengatasi Masalah Narkoba dengan Welas Asih. Jakarta: Gramedia Pustaka Utama. Retrieved from http:// lms.bpkpenaburjakarta.or.id/SMAKGS/index.php?p=show_ detail\&id $=7881$

Tim Penyusun Kementerian Agama RI, L. 2016. Tafsir Ilmi, Mengenal Ayat-Ayat Sains dalam Alqur'an. Jakarta: PT Widya Cahaya.

Todora Rogelja, M. A. S. 2017. Structural power in Serbian anticorruption forest policy network. Forest Policy and Economics, 82(June), 52-60. https://doi.org/10.1016/j.forpol.2017.05.008 
Umam, M. H. 2013. Pandangan Islam tentang Korupsi. Teosofi: Jurnal Tasawuf Dan Pemikiran Islam, 3, 462-482.

Zulfitria. 2016. Pembelajaran Tahfidz Al-Quran Dalam Pendidikan Karakter Anak Usia Dini (PAUD). Darul Ilmi Jurnal Ilmiah Pendidikan Islam Anak Usia Dini, Volume 1 N, 35. 